\title{
STATUS, APPROPRIATE SAMPLING SCHEME, AND MOVEMENT IN THE TIGER SALAMANDER (AMBYSTOMA TIGRINUM) IN YellowSTONE NATIONAL PARK
}

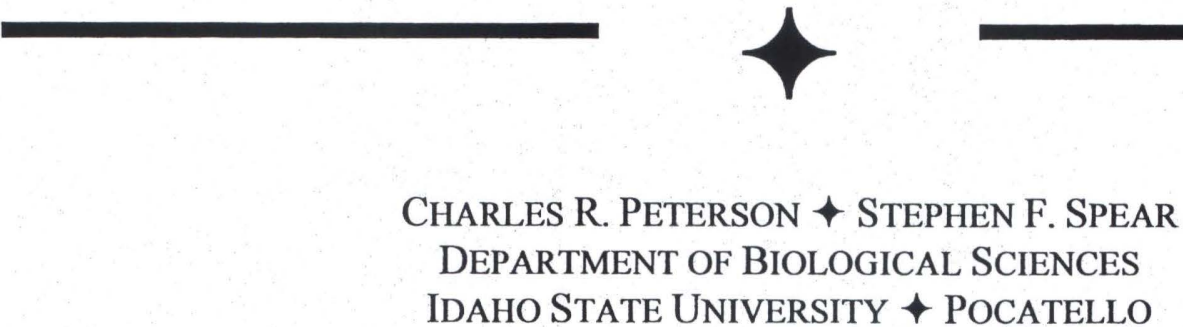

\section{$\uparrow \quad$ INTRODUCTION}

Due to the current trend of amphibian declines (Wake 1998, Alford and Richards 1999, Semlitsch 2000), the monitoring and study of amphibian populations has become increasingly necessary. To properly do such studies, we must consider several issues. Some of these include the detectability of the species at a site, current status of the population, and the spatial scale for sampling of a population. Determining the detectability of a species is important to consider because some amphibian species may have different difficulties of detection. Therefore, if a species is difficult to observe, it may occupy a greater number of sites than a survey indicates (MacKenzie et al. 2002). The appropriate spatial scale is also important for monitoring studies. For example, in a pond breeding amphibian, do one or two breeding ponds with the appropriate terrestrial habitat constitute the correct sampling area for a population, or does a population utilize multiple ponds within a larger terrestrial area? If the sampling scale is not appropriate, then any conclusions made may be inaccurate (Wiens 1989).

In addition, understanding the terrestrial habitat use of pond breeding amphibians is important for both monitoring and conservation reasons. Many pond-breeding amphibians use the ponds for breeding and then utilize terrestrial zones around the pond for the rest of the year. The total area that is encompassed by these terrestrial zones is known as the terrestrial "buffer zone" or core habitat area for that population (Semlitsch 1998). To identify these core habitat areas, we must know not only the distance that the amphibians physically move from the breeding pond, but also the type of habitat that they will use. For example, short, steep slopes or rivers can serve as a barrier to amphibian movement (Laan and Verboom 1990, Storfer 1999), even if they are within the movement range of a population. Understanding individual movement may also give insights into the spatial population structure of the species. If we can identify the average distance of movement, we can then extrapolate if a breeding pond is likely to have an isolated subpopulation based on its distance from other ponds.

\section{$\uparrow \quad$ OBJECTIVES}

The objectives of this study were to survey sites and track tiger salamanders in the Slough Creek area of Yellowstone National Park to:

(1) calculate detection probabilities using two different sampling techniques;

(2) estimate current status;

(3) detect any changes in status based on surveys done in 1992 and 1993;

(4) indicate what the appropriate sampling scheme is for this species in Yellowstone;

(5) describe the amount and type of terrestrial habitat that is used. 


\section{Future Work/Recommendations}

To gain insights into the spatial population structure of this area, we are beginning a project in 2003 examining the gene flow of tiger salamanders across the northern range of Yellowstone National Park. This study will include the Slough Creek area that was the focus of this study, but also extend from the Mammoth area to Lamar Valley east of Slough Creek. We will sample from 12-15 ponds of varying distances apart from each other and estimate the amount of gene flow between different ponds. In addition, we will investigate whether wetland connectivity across the landscape has an effect on the genetic structure among the ponds. This will not only give insight into the population structure of the salamanders in the northern range, but will also have implications for tiger salamander terrestrial movement. For example, if ponds separated by dry land tend to be isolated from each other, it may indicate that the salamanders do not move large distances terrestrially.

\section{$\uparrow \quad$ ACKNOWLEDGEMENTS}

Several organizations and individuals helped with this study. Funding for this study was provided by The University of Wyoming - National Park Service Research Center, the Idaho State University Graduate Student Research and Scholarship Committee and the Idaho State University Department of Biological Sciences. We would like to thank the National Park Service and Yellowstone National Park for allowing us to do this study in the park. Christie Hendrix assisted us with obtaining the necessary park permits and Colette Daigle-Berg and other park rangers helped us coordinate our field activities so that they did not conflict with any park regulations or closures. Denim Jochimsen, Debra Patla, and Jeremy Piersol assisted with field work.

\section{$\uparrow \quad$ Literature Cited}

Alford, R.A. and S.J. Richards. 1999. Global amphibian declines: a problem in applied ecology. Annual Review of Ecology and Systematics 30: 133-165.
Hill, S.R. and R.E. Moore 1994. Herpetological survey in the northern range of Yellowstone National Park. Annual Report to Yellowstone National Park.

Laan, R. and B. Verboom. 1990. Effects of pool size and isolation on amphibian communities. Biological Conservation 54: 251-262.

MacKenzie, D.I., J.D. Nichols, G.B. Lachman, S. Droege, J.A. Royle, and C.A. Langtimm. 2002. Estimating site occupancy rates when detection probabilities are less than one. Ecology 83: 2248-2255.

Semlitsch, R.D. 1998. Biological delineation of terrestrial buffer zones for pond-breeding salamanders. Conservation Biology 12(5): 1113-1119.

Semlitsch, R.D. 2000. Principles for management of aquatic-breeding amphibians. Journal of Wildlife Management 64(3): 615-631.

Storfer, A. 1999. Gene flow and population subdivision in the streamside salamander, Ambystoma barbouri. Copeia 1999(1): 174181.

Wake, D.B. 1998. Action on amphibians. Trends in Ecology and Evolution 13: 379-380.

Wiens, J.A. 1989. Spatial scaling in ecology. Functional Ecology 3:385-397. 